\title{
Career and salary of a university teacher: personnel policy regulation in Russia
}

\section{Carreira e salário de um professor universitário: regulamento da política de pessoal na Rússia}

\section{Carrera y salario de un profesor universitario: regulación de la política de personal en Rusia}

\author{
Elena Ivanovna Kuznetsova ${ }^{1}$ (D), Dmitry Vladimirovich Dianov ${ }^{1}$ iD, \\ Umeda Akparovna Ovezova² (iD, Alexey Viktorovich Suslov ${ }^{3}$ (iD), \\ Tatiana Sergeevna Markova ${ }^{3}$ iD
}

\footnotetext{
${ }^{1}$ Moscow University of Ministry of Internal Affairs of Russian Federation named after V.Ya. Kikot, Moscow, Russian Federation.

2 Peoples' Friendship University of Russia (RUDN University), Moscow, Russian Federation.

${ }^{3}$ Russian State Social University, Moscow, Russian Federation.
}

\section{Corresponding author:}

Elena Ivanovna Kuznetsova

Email: elenkuz90@mail.ru

How to cite: Kuznetsova, E. I., Dianov, D. V., Ovezova, U. A., Suslov, A. V., \& Markova, T. S. (2021). Career and Salary of a University Teacher: Personnel Policy Regulation in Russia. Revista Tempos e Espaços em Educação, 14(33), e16267.

http://dx.doi.org/10.20952/revtee.v14i33.16267

\begin{abstract}
The present article explores the problems of personnel policy in the higher education system concerning the incentive role of remuneration and career development opportunities. At present, due to several major socio-economic changes, a transformation of labor relations in the system of higher education is taking place. As a result, new approaches to both the management of educational institutions and the selection of university faculty and the remuneration and career development of teachers are required. The goal of the study is to analyze individual modern trends in the development of incentive methods in higher education as a feature of personnel policy. The article demonstrates that as a consequence of the economic transformations, changes requiring an increase in the quality of graduates are occurring in university management which inevitably influences the expansion of the professional requirements for teaching staff. It is established that in modern conditions, external control is replaced by internal one, academic freedoms are displaced by the administration, and academic standards are modified and replaced by formal rules. This process is accompanied by considerable changes in the university personnel policy and the relationships between the administration and teachers. Various examples of human resources policy organizations adopted in different countries are studied. The features of labor contracts with
\end{abstract}


teachers, the conditions of their work, and career opportunities are investigated. Special attention is paid to various approaches to stimulating teaching activity. The shortcomings that do not allow achieving a higher quality of higher education in Russia are identified. Proposals for improving personnel policy in higher education aimed at improving its quality are presented.

Keywords: Higher education. Teaching activity. Labor relations. Labor incentives for teachers. Personnel policy.

\section{RESUMO}

O presente artigo explora os problemas da política de pessoal do sistema de ensino superior no que diz respeito ao papel incentivador da remuneração e das oportunidades de desenvolvimento de carreira. Atualmente, devido a várias mudanças socioeconômicas importantes, está ocorrendo uma transformação das relações de trabalho no sistema de ensino superior. Como resultado, são necessárias novas abordagens tanto para a gestão de instituições educacionais quanto para a seleção de professores universitários e a remuneração e desenvolvimento de carreira de professores. O objetivo do estudo é analisar as tendências modernas individuais no desenvolvimento de métodos de incentivo no ensino superior como uma característica da política de pessoal. $\mathrm{O}$ artigo demonstra que, como consequência das transformações econômicas, estão ocorrendo na gestão universitária mudanças que exigem o aumento da qualidade dos graduados, o que inevitavelmente influencia na ampliação das exigências profissionais para o corpo docente. Estabelece-se que nas condições modernas, o controle externo é substituído pelo interno, as liberdades acadêmicas são deslocadas pela administração e os padrões acadêmicos são modificados e substituídos por regras formais. Este processo é acompanhado por mudanças consideráveis na política de pessoal da universidade e nas relações entre a administração e os professores. Vários exemplos de organizações de políticas de recursos humanos adotadas em diferentes países são estudados. São investigadas as características dos contratos de trabalho com professores, as condições de seu trabalho e as oportunidades de carreira. É dada atenção especial a várias abordagens para estimular a atividade de ensino. São identificadas as deficiências que não permitem alcançar uma educação superior de maior qualidade na Rússia. São apresentadas propostas de aprimoramento da política de pessoal no ensino superior, visando à melhoria de sua qualidade.

Palavras-chave: Ensino superior. Atividade de ensino. Relações de trabalho. Incentivos de trabalho para professores. Política de Pessoal.

\section{RESUMEN}

El presente artículo explora los problemas de la política de personal en el sistema de educación superior relacionados con el papel incentivador de la remuneración y las oportunidades de desarrollo profesional. En la actualidad, debido a varios cambios socioeconómicos importantes, se está produciendo una transformación de las relaciones laborales en el sistema de educación superior. Como resultado, se requieren nuevos enfoques tanto para la gestión de las instituciones educativas como para la selección del profesorado universitario y la remuneración y el desarrollo profesional de los profesores. El objetivo del estudio es analizar las tendencias modernas individuales en el desarrollo de métodos de incentivos en la educación superior como una característica de la política de personal. El artículo demuestra que como consecuencia de las transformaciones económicas, se están produciendo cambios en la gestión universitaria que requieren un aumento de la calidad de los egresados, lo que inevitablemente influye en la ampliación de las necesidades profesionales del profesorado. Se establece que en las condiciones modernas el control externo es reemplazado por el interno, las libertades académicas son desplazadas por la administración y los estándares académicos son modificados y reemplazados por reglas formales. Este proceso va acompañado de cambios considerables en la política de personal 
universitario y las relaciones entre la administración y los docentes. Se estudian varios ejemplos de organizaciones de políticas de recursos humanos adoptadas en diferentes países. Se investigan las características de los contratos laborales con los docentes, las condiciones de su trabajo y las oportunidades profesionales. Se presta especial atención a varios enfoques para estimular la actividad docente. Se identifican las deficiencias que no permiten lograr una mayor calidad de la educación superior en Rusia. Se presentan propuestas de mejora de la política de personal en la educación superior orientadas a mejorar su calidad.

Palabras clave: Educación más alta. Actividad docente. Relaciones laborales. Incentivos laborales para docentes. Política de personal.

\section{INTRODUCTION}

The objective of the modern education system lies in ensuring the conditions for the formation of the quality of human capital corresponding to the technological level of modern social production (Bukhteeva et al., 2019; Sekerin et al., 2018). Education is currently becoming a major source of competitive advantage for both individual firms and national economies (Tereshchenko et al., 2020). While in the middle of the 20th century only $20 \%$ of jobs required highly qualified personnel, today, according to experts, the share of such jobs reaches $60 \%$ and is going to rise in the future (Kolin, 2002). Experts indicate that the development of information society will require $40-60 \%$ of the adult population to have higher education (Abdulkadyrov et al., 2021). Today, the educational level of the population acts as the main driver of socio-economic development. Considering the Russian economy, IMF analysts note that "...spending on education, health care, and infrastructure is necessary to maintain competitiveness" (Zhandarova, 2017). This opinion is shared by the leading Russian economists. S. Glazev (2016) states that in the context of another shift in the technological structure, the main driving sectors will be health care, education, and science which will account for more than $50 \%$ of the country's gross domestic product.

Same as any other productive activity, the educational activity requires the presence of the means and subjects of labor, as well as manpower. However, in the sphere of education, these elements have certain specifics (Orlova \& Parshikov, 2017) The specifics of education as a sector are shaped by its belonging to the non-productive sector of the economy creating not material but intellectual products or services. This benefits not only an individual improving their level of education but also society as a whole (Goncharov et al., 2020). In education, the subject of labor is not matter but a person. Scientific and pedagogical workers are the main factor of the production processes in education. The specificity of those employed in this industry is the high level of education. The sphere of education is generally characterized by a high proportion of mental, skilled labor. The process of providing educational services also involves engineering, administrative, support, and other employees charged with auxiliary functions. The qualifications and quality of scientific and pedagogical employees determine the level of training to a crucial extent in higher education. The creative component must be present in all activities of a teacher (educational, teaching and methodological, research, communicative, organizational). Experts note that the creative competence in pedagogical activity comprises "a system of knowledge, skills, abilities, and, most importantly, personal qualities necessary for a teacher's creativity as a teacher, researcher, organizer, leader" (Kim \& Lisienko, 2012, p. 16). The work of teaching staff is associated with an increased level of psycho-emotional and intellectual load which should be reflected in modern labor relations in the system of incentives for teachers and opportunities for their career development.

The Russian system of labor relations is going through a prolonged transformation crisis and this statement can to a certain extent be extrapolated on the sphere of higher education. With the rapid development of the global economy, Russian higher education should be set up for effective economic development and the needs of society. The effective functioning of higher education has to be based on the coherence and satisfaction of the interests of all its subjects including the social 
and labor ones. Therefore, the study of the peculiarities of modern labor relations in the system of higher education appears extremely relevant today.

The issues of regulating various aspects of labor relations in higher education under the conditions of its transformation are becoming extremely relevant today. This relevance draws the interest of many researchers to the problems of organizing teachers' professional activity and stimulating their work. The works of such authors as M.V. Kurbatova (2016), G.lu. Lazareva (2020), and N.N. Orlova (2017) make a significant contribution to the base of knowledge on the peculiarities of teachers' professional activity under the conditions of the transformation of the higher education system, however, we cannot yet conclude on the sufficiency of this base. Therefore, the search for new ways of improving the effectiveness of pedagogical activity based on various incentives for teachers carried out in the present article should be of some scientific and practical interest. The study hypothesis states that in the modern Russian conditions, it seems appropriate to introduce the incentive methods of an "effective contract" system to improve the quality of teaching in higher education.

\section{METHODS}

The present study was conducted using a set of general scientific approaches: the generalist, statistical, and comparative ones. The first approach allows examining the object of the study as a social community with its specific characteristics. Statistical analysis allows USA to see the latter in their dynamic (according to the official statistics) and evaluate their impact on the qualitative and quantitative changes in the higher education system. Comparative analysis allows determining the direction of the development of labor relations accounting for diverse international experience. The study hypothesis was tested using legal information found in legal reference systems, theoretical provisions presented in published scientific works, and statistical data available on official websites.

\section{RESULTS}

Social and labor relations cover a wide range of processes and relations between them arising from human participation in social production. At the same time, labor relations, i.e. the relationship between labor and capital, serve as the basis of social and labor relations implementing the human rights to work and receive labor income from participation in social production. The interaction between the employer and the employee signifies the formation of labor relations while the participation of the state in these relations marks the formation of social and labor relations. The devaluation of labor values and the undervaluation of highly skilled intellectual labor have manifested, among other things, in a deep crisis of social and labor relations in Russia and have become one of the most serious problems of the socio-economic development of the country. This crisis is evident in many sectors of the Russian economy but is observed especially clearly in the education system, particularly in higher education (Orlova \& Parshikov, 2017).

The specifics of higher education are primarily shaped by the specifics of pedagogical labor. The professional activities of scientific and pedagogical employees are carried out under the condition of relatively higher requirements for them compared to the employees of most organizations outside the educational sector. Therefore, the system of social and labor relations in an educational organization should focus not only on improving the efficiency of university staff but also on creating conditions for social protection (Orlova \& Parshikov, 2017).

Modern Russian research demonstrates that reforms of the Russian education system cause universities to demonstrate the same effects as were observed in other countries due to the implementation of new public management instruments (Kurbatova, 2016). The conceptual foundation for reforming the system of higher education management was formed by the approaches of the new public management the essence of which lies in transferring the methods of 
the private sector to the public sector. The old systems of state regulation of this sector are dismantled and replaced by quasi-market structures. The transition to quasi-market structures means the creation of competitive mechanisms for universities - normative per capita financing, competitive distribution of budget places, etc. Meanwhile, it should be noted that the consequences of the implementation of these mechanisms are quite ambiguous which is reflected by several studies. In the Russian Federation, the state (a state agency) is currently involved in the provision of services through a management hierarchy in which superiors give orders or instructions regarding the service to their subordinates (goal-setting and result evaluation management). The criteria for the quasi-market evaluation of universities that have to provide the indicators of their effectiveness include the "entry" indicators (USE scores), the "exit" indicators (employment), performance indicators (primarily the volume of scientific research works). The management of goal-setting and result evaluation has factually become a tool for overcoming institutional resistance in the university professional community that is breaking the model of trust and turning professionals into a part of the managerial hierarchy. The consequences for the work of university teachers are profound and in many ways irreversible. Recent institutional research draws attention to the fact that, in the public sector, private sector techniques for evaluating results and improving the performance of organizations and workers often produce different results than expected. Turning universities into client-oriented organizations and making faculty members regular employees is fundamentally changing the organizational culture and incentives (Deem, 2004). The position of teachers is changing, "managers are starting to play a more important role than academics" (Head, 2011, p. 282). At the same time, there forms a "bureaucratic vertical working based on the principle of command control" of teachers' activities aimed at demonstrating the efforts to provide a "quality product" to the funding sources (Head, 2011). The incentives based on the current informal norms of academic standards for a given professional community and the reputational control mechanisms are being replaced by the incentives determined by the quasi-market conditions artificially created by the state and the corresponding mechanisms of external evaluation and control. Said mechanisms force universities to work on the indicators (Tambovtsev, 2006). The literature describes the effects observed in countries implementing the mechanisms of the "new state management" including increased dependence of teachers on faculty and university administration, the development of competition for jobs, and increased workload of teachers (Gill, 2009).

Despite the new economic opportunities that university administrations received in the 1990s, before the start of the higher education system reformation, the rectorate had been remaining a part of the university community. The rectorate was delegated from the university community and was accountable to it. The work of the rector and vice-rectors was remunerated by the state on general principles: the salary was set by a unified tariff system and receiving income from extrabudgetary funds legally required the decisions of academic councils.

Significant shifts in the state of university management and intra-university relations started to occur increasingly with the introduction of a new labor remuneration system introduced by the Russian Federation Government Decree No. 583 of August 5, 2008 (Government of the Russian Federation, 2008). This system was based on the state delegating the authority to form remuneration systems to university administrations turning the latter into the sole employer of teachers. The power of administrations gradually changed in several ways: at the level of universities, staffing schedules started being approved and wage funds started being formed. The system of estimated financing was replaced by the provision of subsidies for the performance of the state task. University administrators transformed from members of the university community into the managers and employers of teachers. Their income was made dependent on the decisions of the founder (first the Federal Agency of Education of the Russian Federation, and then the Ministry of Education and Science of the Russian Federation). These changes were supported by changes in the university financing principles, the introduction of performance indicators, as well as changes in 
the practice of electing rectors that started to resemble appointments. The next step to building the vertical of administrative control was associated with the adoption of the "Program for the Step-byStep Improvement of the System of Payment for Labor in State (Municipal) Institutions for 20122018" (approved by the Russian Federation Government Decree No. 2190-r of November 26, 2012) (Government of the Russian Federation, 2012). The state establishes "framework conditions" for the formation of wage systems by universities, creates criteria for bureaucratic evaluation of the performance of universities and teachers, and establishes parameters for the formation of wage funds.

The May Decrees of the President of the Russian Federation of May 7, 2012, No. 597 "On measures to implement the state social policy" (President of the Russian Federation, 2012a) and No. 599 "On measures to implement state policy in education and science" (President of the Russian Federation, 2012b), as well as large-scale national projects "Education" and "Science", have determined several new requirements for the quality of higher education. At the same time, the issue of ensuring competitive salaries for teaching staff was resolved and major projects to upgrade the material and technical base of educational institutions were implemented. Simultaneously, university administrations are establishing their remuneration systems and conclude contracts with faculty members differentiated according to their "contribution" to the results of the university's activities identified in the course of the bureaucratic evaluation. Salary raises are linked to the establishment of "real incentive payments" and "the need to link the increase in wages to the achievement of specific indicators of quality and quantity of public (municipal) services (work)" is proclaimed. University professors are becoming employees and the system of professional community control over university administrations is collapsing. The "Program for the Step-by-Step Improvement of the System of Payment for Labor in State (Municipal) Institutions for 2012-2018" factually consolidates the transformation of teachers into "cogs" in the production of educational services: they are evaluated according to "an interconnected system of sectoral performance indicators from the federal level to a specific institution and employee". While the Russian Federation Government Decree No. 583 of August 5, 2008, stipulated that incentive payments should be established "taking into account the indicators and criteria for evaluating the work of teachers developed in the institution", the "Program for the Step-by-Step Improvement of the System of Payment for Labor in State (Municipal) Institutions for 2012-2018" established a different objective of incentive payments - they had to be tied "to the achievement of specific indicators of quality and quantity of the provided public services".

The set of implemented measures undoubtedly allowed to draw attention to the fact that the scientific, technical, and technological development as a factor of "university" growth and increased competitiveness of the Russian education is reaching a new level ensuring not only the effective solution of internal tasks but also several Russian universities entering international university ratings. However, despite the measures that have been and are being implemented, the human resources problem of educational institutions remains very serious, primarily in terms of categories of teaching staff and researchers. In the last two years, the average age of university teaching staff increased due to a reduction in the number of young workers (and a decrease in the share of this category in the total number of teachers). While the number of employees in educational organizations decreased by 7\% in 2019 compared to 2017, the number of teaching assistants and teachers decreased even more, by almost 9.4\% (!) (All-Russian Trade Union of Education, 2016). In the same period, the number of researchers also reduced (although not as significantly, only by $1.3 \%$ ). Aside from the lowered number of young researchers and teachers, statistics indicate a decrease in their quality characteristics. For example, the number of teaching assistants and professors with academic degrees decreased by $28.8 \%$ (!) (TRUD.com, n.d.). All these facts demonstrate the ineffectiveness of the system for stimulating teaching work. 


\section{DISCUSSION}

Let USA consider the specifics of solving staffing problems in higher education in countries that have differences from the Russian system of staffing. Personnel policy in the field of higher education is arranged differently in different countries but generally involves different degrees of formal control of the process of "entry" of a new member of a self-governing corporation by the state and officials at different levels. In France, for example, the state establishes a set of formal restrictions, requirements, and filters for hiring academics. The requirements of nationwide competition passing which is mandatory to obtain a position at a university or even apply for a vacancy have led to academic recruitment being largely based on scholars' demonstration of certain formal indicators of "advancement" in their careers (publications, etc.) (Sokolov et al., 2015).

A polar opposite model is observed in Germany where professors alone decide who to hire and what requirements to pose without having to report about their reasons for favoring one candidate over another to anyone. The only restriction has to do with the prohibition of inbreeding (hiring one's graduates). The teaching staff includes professors and researchers (Wissenschaftliche Mitarbeiter) (Khudaimuratova, 2020). Researchers are hired on a temporary and usually part-time basis when there is an increase in outside funding for educational research. When teaching at the university, such researchers are not paid in full in accordance with the staffing schedule. They are only paid for the hours during which they teach students meaning they are only paid for teaching.

The employment of university researchers in Germany is concluded for a fixed term in accordance with the German Academic Fixed-Term Contracts Act of April 12, 2007 (Bundesministeriums der Justiz und für Verbraucherschutz, 2007). According to this law, individuals with a master's degree or doctoral students may be hired as research fellows. A three-year employment contract is signed with such a researcher under the condition that they work on their doctoral dissertation at the same time and typically must defend it afterward. As a compromise, said contract can be extended for another three years. In addition, such researchers must teach the required four hours per week in various scientific fields and their classes usually have to involve a seminar or exercises. As a rule, the indicated scientific fields are the ones in which the researcher has to defend the thesis they are preparing. In parallel, a researcher may engage in outside employment, office, or production, including overseas. At the end of these six years, the researcher either becomes a doctoral candidate or is forced to leave the university to pursue other activities (Bode et al., 2015). A postdoctoral research fellow is required to work at the university for at least $60 \%$ of full-time employment and the remaining time can be used for research or office and production work, including work overseas.

A professor in the field of fundamental research remains in this position until retirement age. The position of professor customarily implies being tied to a department in the area of research determined by the head of the department (Khudaimuratova, 2020).

Only candidates with a doctoral degree which implies the successful defense of a doctoral dissertation may be hired as a professor.

This scientific degree is currently subject to public criticism and may be revoked or changed in the future (Hasselhorn et al., 2014). Aside from the position of professor (Ordentliche Professur), the position of a junior professor was introduced in Germany corresponding to that of Assistant Professor in England and the United States and Associate Professor in Russia. In this case, scientists who have defended a doctoral dissertation can hold the position of a professor but for no longer than six years. After this period, they must become professors on a competitive basis (Ergasheva, 2019).

It should be noted that salaries in higher education in Germany are slightly higher than the national average. While the average monthly wage for manufacturing and services in Germany in 2012 was 3,700 euros, higher education pay which is dependent on tuition averaging at 5,000 euros 
per month is 3,900 euros and professors earn an average of 7,500 euros per month (Khudaimuratova, 2020).

As for additional opportunities for financial incentives, the "Teaching in Higher Education Quality Model" (THEQM) is common in Europe (Pouyioutas, 2017). This model provides recommendations (11 in total) on the quality of education in universities and, in turn, universities use these recommendations and make adjustments to them based on their strategies. Each of these recommendations is divided into 9 indicators, each of which should help to get the most productive results. One of the recommendations specifically concerns financial incentives for teachers, thus, we would like to explore it in more detail. THEQM advises higher education institutions to reward faculty members who directly contribute to improving students' learning through a variety of stipends, bonuses, and other fringe benefits. The question arises as to how to determine how well an employee is doing their job. For this purpose, the model provides 9 indicators that should determine the policy of an institution: rewards for improving teaching methods (as students' learning depends on it), rewards for learning quality (indeed, students may be present in classes, for example, but how much they have learned is an entirely different thing), for students' grades (which can be argued since grades are a relatively subjective indicator that may not correspond to reality), rewards for research in teaching and learning, as well as its practical implementation (this can greatly help the university to improve the quality of teaching and, therefore, its rating), awards for teaching using new technologies, for motivating students to take part in political life, for high scores on the "Best Teacher" survey (also definitely a subjective opinion) and, most importantly, the institution should publicly recognize those who have been rewarded as it provides additional motivation for further victories (Gibadulina \& Kamneva, 2020). Some indicators are subjective which means a possible discrepancy between the received payments and the real results since it also happens that sometimes a student grades a teacher poorly simply because, for example, they once made them a remark while the teacher themselves is a good specialist but their reward will suffer nonetheless.

In the USA, according to official data, there are more than 600 public and about 1,800 private universities and colleges with a four-year cycle of study which correspond to Russian higher education (Gladkikh, 2005). Meanwhile, the system of higher education is highly decentralized: none of the universities is funded from the federal budget and the status of a State University means that the university belongs to a specific state of the country and is financed from its budget (Rimskaia, 2006). The faculty position structure in the United States has four levels (Dzonstoun, 2003): 1) instructor (graduate-assistants); 2) assistant-professor; 3) associate-professor; 4) professor (full professor). A characteristic feature of the American faculty structure is the forced incentive to intensify teaching and research activities by limiting the tenure and selection of faculty members at the first two levels and lifetime appointments to the third and fourth levels. Overall, the system works in such a way that teaching staff is distributed evenly across all four levels and, therefore, by age (Maiburov, 2003). It should be noted that a faculty member at a USA university is primarily involved in three types of activities: 1 . Teaching (a standard load is set as several courses per semester or per year). 2. Research activities (a faculty member must actively publish research papers). 3. Organizational and administrative activities (a faculty member administers educational programs or activities, participates in the work of various committees) (Umurakova \& lantilina, 2018). Like in many higher education institutions in the country, there are both financial and nonfinancial incentives at USA higher education institutions. The main financial incentive is salary the level of which can be increased as a result of an evaluation. At most universities, each teacher is entitled to be paid to attend two scientific conferences a year under the condition that their paper is accepted at that conference. Sometimes funding does not cover all the costs of participation in a conference and a teacher participates in funding it themselves since participation in conferences is an important factor in the evaluation of the quality of their work (Grishina et al., 2015). The level of 
pay for employees in the field of education directly depends on whether they have an academic degree. The highest salaries are paid to professors (about $27 \%$ of all teachers). The lowest salaries are paid to rank-and-file and non-degree teachers (26\%). Significant differences are observed in pay for teachers and professors depending on the type of institution. In the private sector, the pay gap for teachers at various higher education institutions is more than $\$ 43,000$ with salaries ranging from $\$ 42,000$ at two-year colleges to $\$ 85,300$ at universities. At public universities, the gap is smaller at $\$ 16,700$ (\$57,400 and $\$ 74,100$, respectively) (Kleri, 2008). In addition to the base salary, each USA professor has individual funds in the department's budget for research conferences and travel. Additional payments for advising, research, and lecturing at other institutions range from 18 to $22 \%$ of the established salary. Many institutions have annual benefits for university teachers (pension fund contributions, health insurance, social security, life insurance, etc.). It should also be noted that a scientist has the right to use paid leave while preparing a dissertation and writing books which is paid at the rate of $100 \%$ of earnings for six months or $50 \%$ of annual earnings. Thus, having sufficient income to meet their material needs, the teaching staff of USA higher education institutions can devote their full working time to science and be constantly improving their knowledge (Rimskaia, 2006).

Connie Chairunnisa and Ahmad Kosasih (2019) studied academic culture in a higher education institution and found that a favorable academic culture has a direct positive impact on the academic activity of scientific and pedagogical staff, as well as their commitment. Based on the obtained results, the authors suggest that an academic culture that supports the innovative activity of academic staff and provides faculty members with more freedom and independence in carrying out academic activities should be fostered. Martina Blaskova and Kristina Trskova (2017) from the University of Zilina, Slovakia state that a high level of motivation was reached by the employees working in an atmosphere of trust and friendliness with the opportunity to implement their ideas, that is, those whose managers use creative leadership. The authors note the presence of multifactorial impact on the activities of scientific and pedagogical staff and consider leadership style one of the important factors determining the effectiveness of university employees' innovative activities. The authors conclude that the higher is the motivation of higher education institution management to implement creative leadership, the higher is the motivation and creativity of the teaching staff.

We would also like to note the following motives continuing to play an important role in the professional activities of teachers: - self-affirmation; - spiritual growth; - self-realization. Although external motives still do not serve as the main factors in motivating and controlling the activities of a teacher, the importance of these factors is growing. This tendency is most pronounced in the American academic environment where the levers of control nclude social status, the high prestige of the profession of a teacher in higher education, and quite high pay (Gibadulina \& Kamneva, 2020).

Thus, the problem of stimulating teaching activity is relevant and important. In foreign countries, the system of incentives for employees in the field of education is based on assessing the qualifications and business and personal qualities of teachers. Despite that the criteria for evaluating the performance of teachers vary across different universities, they all tend to include teaching skills, research results, the attitude towards work, the level of professionalism, the results of creative activity, past achievements, and motivation to use new teaching methods.

For modern Russia, one of the promising ways to stimulate the work of scientific and pedagogical employees is an effective contract described by M.V. Kurbatova and S.N. Levin (2013). An effective contract is a contract between a faculty member and a university that guarantees a high level of remuneration for meeting certain indicators required by the university. In particular, the employment contract with each employee must clarify and specify labor duties, performance indicators and criteria, the amount of remuneration, the volume of incentives for achieving collective labor results and ensure the transparency of remuneration (the terms of remuneration 
must be clear to the employer and the employee and not allow for double interpretation). Currently, the system of effective contracts is used by several universities, such as the Moscow Institute of Physics and Technology, the National University of Science and Technology "MISIS", the National Research University "Higher School of Economics", the National Research Nuclear University "MEPhl", Peter the Great St. Petersburg Polytechnic University, the Ural Federal University, the National Research Tomsk State University, the Novosibirsk National Research State University, and others. The experience of stimulating scientific and pedagogical employees through concluding a mutually beneficial contract with a teacher is examined on the example of the Higher School of Economics by Dr. I. B. Nazarova. Currently, under the terms of the contract, the mutual obligations of the faculty member and the Higher School of Economics include (Nazarova, 2014): the university's obligations to not only provide a scientific and pedagogical worker with financial support but also create the conditions necessary for their effectiveness; requirements for the teaching, administrative, and research activities of the employee; the teaching load is reduced without losses in wage for the teachers who have publications in Scopus or Web of Science international databases; $10-50 \%$ bonuses for Ph.D. degrees and members of the university's personnel reserve if they have administrative workload; paid assistants can be provided for more effective work; the availability of paid sabbatical leave for scientific and pedagogical employees who have worked at the university for more than five years. The authors distinguish two main types of contracts: for teachers who choose the path of a teacher and for those who are ready to choose the role of a teacher"researcher". The teacher-"teacher" contract implies that a significant portion of working time will be devoted to teaching and achievements in the field (60-70\% of employment). Such faculty members may devote considerably less time to scholarly work (10-30\%) and approximately the same amount of effort to organizational, social work (10-20\% of the time). Within the framework of this contract, an employee has to be more engaged in teaching and perform relevant activities (most importantly, create educational and methodological materials, supervise theses, supervise master's theses, prepare students for participation in Russian and foreign scientific work competitions). The contract of a teacher-"researcher" emphasizes research activities (60-70\% of the time), teaching has a smaller share in the total teaching load (10-30\% of the time), and organizational and social work makes up $10-20 \%$ of a teacher's time at the university. A teacher- "researcher" is less engaged in teaching activities but must prepare graduate students for defense and publish, for example, at least two articles in a journal refereed in WOS and SCOPUS and two articles indexed in the Russian citation database (RSCl) in two years. A.R. Alaverdov (2015) considers new strategic approaches to stimulating scientific and pedagogical employees. Within the framework of financial incentives, it is proposed to expand the list of factors influencing the volume of additional payments to scientific and pedagogical employees. The author identifies several conditions for the fulfillment of which scientific and pedagogical employees should be additionally paid $10-25 \%$ of the base salary. For achieving a citation index corresponding to the held position, as well as for creating and teaching original courses, it is suggested to pay up to $25 \%$ of the base salary. Academic staff teaching courses in a foreign language may receive an additional payment of $20 \%$ of the base salary. If an academic staff member is a practicing specialist in the relevant field, a supplement of $15 \%$ is offered. Finally, a $10 \%$ bonus is offered for leading a student union and for using innovative educational technology. As a part of the non-financial incentives, two approaches are proposed for implementation: the first one involves increasing the effectiveness of scientific and pedagogical workers through improving their skills (paid internships at universities with a high rating, medium-term retraining programs with a certificate, and short-term training programs with the best specialists in the industry), the second is to hold annual competitions. Within the indicated approaches, incentives are based on the obtained results and do not account for the existing competencies of employees and the age composition of the teaching staff. Thus, having examined the existing methods for stimulating the activity of the teaching staff, we can identify several common features. The authors divide the 
approaches to stimulation into financial and non-financial ones which allows satisfying both financial and psychological needs of scientific and pedagogical employees and is important for employees engaged in teaching activities. However, within the framework of the proposed methods, most of the incentives will be received by highly competent employees already having extensive experience in scientific activities while assistants and young teachers who do not have a sufficient competence level will not be full participants in the developed system. In this regard, there is a need to differentiate the scientific and pedagogical staff by age and profession to ensure that young professionals strive to self-educate, improve their competencies, and engage in innovative activities (Nazarova, 2014).

The conducted studies allow USA to present a comparative characteristic of personnel policies in the sphere of higher education for different countries in the form of a table (Table 1).

Table 1. A comparative characteristic of personnel policies in the sphere of higher education for different countries.

\begin{tabular}{|c|c|c|c|c|}
\hline \multicolumn{5}{|c|}{ Key elements of personnel policy in higher education } \\
\hline \multirow[b]{2}{*}{ Country } & \multirow{2}{*}{$\begin{array}{l}\text { Recruitment } \\
\text { features }\end{array}$} & \multirow[b]{2}{*}{ Financial incentives } & \multicolumn{2}{|l|}{ Non-financial incentives } \\
\hline & & & $\begin{array}{l}\text { Career } \\
\text { stimulation }\end{array}$ & $\begin{array}{l}\text { Systemic environmental } \\
\text { stimulation }\end{array}$ \\
\hline USA & $\begin{array}{l}\text { Hiring decisions } \\
\text { are made by the } \\
\text { university } \\
\text { administration at } \\
\text { the suggestion of } \\
\text { the community } \\
\text { of professors }\end{array}$ & $\begin{array}{l}\text { High salaries and additional } \\
\text { payments: for consulting, } \\
\text { research work, lectures at } \\
\text { other universities, annual } \\
\text { benefits for university } \\
\text { professors (contributions to } \\
\text { the pension fund, health } \\
\text { insurance, social insurance, life } \\
\text { insurance, etc.), paid leaves } \\
\text { during the preparation of } \\
\text { thesis and book writing. }\end{array}$ & $\begin{array}{l}\text { Limited tenure and } \\
\text { selection of teachers at } \\
\text { the first two levels and } \\
\text { lifetime appointments } \\
\text { to the third and fourth } \\
\text { levels. }\end{array}$ & $\begin{array}{l}\text { Support for new } \\
\text { scientific research by } \\
\text { the management } \\
\text { (achieved through } \\
\text { providing the necessary } \\
\text { material and technical } \\
\text { base and funding); } \\
\text { social status, high } \\
\text { prestige of the } \\
\text { profession of a } \\
\text { university teacher. }\end{array}$ \\
\hline Germany & $\begin{array}{l}\text { Hiring decisions } \\
\text { are made by a } \\
\text { professor }\end{array}$ & $\begin{array}{l}\text { High salaries and incentive } \\
\text { payments: rewards for } \\
\text { improving teaching methods, } \\
\text { teaching quality awards, for } \\
\text { students' evaluations, awards } \\
\text { for research on teaching and } \\
\text { learning and its practical } \\
\text { implementation, awards for } \\
\text { teaching with the use of new } \\
\text { technologies, for motivating } \\
\text { students to participate in } \\
\text { political life, for high scores. }\end{array}$ & $\begin{array}{l}\text { An employment } \\
\text { contract concluded } \\
\text { under the condition of } \\
\text { working on a doctoral } \\
\text { dissertation and } \\
\text { defending it. After } \\
\text { these six years, the } \\
\text { researcher either } \\
\text { becomes a doctoral } \\
\text { candidate or is forced } \\
\text { to stop working at the } \\
\text { university and pursue } \\
\text { other activities. }\end{array}$ & $\begin{array}{l}\text { Relative freedom in } \\
\text { teaching, social status, } \\
\text { high prestige of the } \\
\text { profession of a } \\
\text { university teacher. }\end{array}$ \\
\hline Russia & $\begin{array}{l}\text { Hiring decisions } \\
\text { are made by the } \\
\text { university } \\
\text { administration } \\
\text { following a set of } \\
\text { formal } \\
\text { restrictions, } \\
\text { requirements, } \\
\text { and filters } \\
\text { established by } \\
\text { the state }\end{array}$ & $\begin{array}{l}\text { Salary is generally higher than } \\
\text { the regional average. } \\
\text { Additional payments (under } \\
\text { the effective contract): for } \\
\text { publications in journals } \\
\text { included in the Scopus or Web } \\
\text { of Science international } \\
\text { databases; the teaching load is } \\
\text { reduced without loss in wages; } \\
\text { 10-50\% bonuses for Ph.D. } \\
\text { degree and members of the } \\
\text { university personnel reserve if } \\
\text { they have administrative load; } \\
\text { paid sabbatical leave to }\end{array}$ & $\begin{array}{l}\text { Providing } \\
\text { opportunities for } \\
\text { professional } \\
\text { development without } \\
\text { loss of pay; Providing } \\
\text { paid assistants to } \\
\text { improve the teacher's } \\
\text { efficiency }\end{array}$ & $\begin{array}{l}\text { Creating an atmosphere } \\
\text { of support for scientific } \\
\text { and organizational ideas } \\
\text { in the team, a general } \\
\text { academic culture within } \\
\text { the team, allowing the } \\
\text { teacher to implement } \\
\text { their ideas, to achieve } \\
\text { self-realization. }\end{array}$ \\
\hline
\end{tabular}


scientific and pedagogical staff who have worked at the university for more than five years.

\section{CONCLUSION}

The conducted research demonstrates that stimulation of labor and career growth of workers in the field of higher education directly affects the quality of training of specialists meeting the requirements of the market economy and management. Therefore, universities are advised to introduce incentive systems stimulating teachers for improving their qualification, career growth, active participation in educational, methodological, and organizational work, as well as the conscientious performance of all their duties. At the moment, such a system can be the "effective contract" adopted in the advanced Russian universities accompanied by differentiating scientific and pedagogical staff by age and profession which will allow striking a balance between teachers' labor interests and solving university staffing problems making it possible to achieve the required quality of training of specialists in higher education. Thus, the study hypothesis appears to be confirmed.

Authors' Contributions: Elena Ivanovna Kuznetsova: conception and design, acquisition of data, analysis and interpretation of data, drafting the article, critical review of important intellectual content. Dmitry Vladimirovich Dianov: conception and design, acquisition of data, analysis and interpretation of data, drafting the article, critical review of important intellectual content. Umeda Akparovna Ovezova: conception and design, acquisition of data, analysis and interpretation of data, drafting the article, critical review of important intellectual content. Alexey Viktorovich Suslov: conception and design, acquisition of data, analysis and interpretation of data, drafting the article, critical review of important intellectual content. Tatiana Sergeevna Markova: conception and design, acquisition of data, analysis and interpretation of data, drafting the article, critical review of important intellectual content. All authors have read and approved the final version of the manuscript.

Ethics Approval: Not applicable.

Acknowledgments: Not applicable.

\section{REFERENCES}

Abdulkadyrov, U. U., Pak, O. A., \& Makushkin, S. A. (2021). Regulation of professional and labor relations of university teachers: international practice and national characteristics. Revista Tempos e Espaços em Educação, 14(33), e15129. https://doi.org/10.20952/revtee.v14i33.15129

Alaverdov, A. R. (2015). Evoliutsiiaa strategicheskikh podlhodov k motivatsii nauchno-pedagogicheskikh rabotnikov [The evolution of strategic approaches to motivating research and teaching staff]. Higher education in Russia, 5, 45-53.

All-Russian Trade Union of Education. (August 22, 2016). K voprosu ob urovne oplaty truda rabotnikov v sfere vysshego, srednego professionalnogo obrazovaniia, nauki [On the issue of the level of remuneration of workers in the field of higher and secondary vocational education and science]. Available:

https://www.eseur.rusK_voprosu_ob_urovne_oplati_tru29112.doc

Blašková, M., \& Trskova, K. (2017). Creative leadership and motivation of university employees. New Trends and Issues Proceedings on Humanities and Social Sciences, 3(4), 23-34. http://dx.doi.org/10.18844/gjhss.v3i4.1510

Bode, C., Becker, W., Habbich, C., \& Klofat, R. (2015). Universities in Germany. London: Prestel.

Bukhteeva, E. E., Zimovina, O. A., Shishov, S. E., Rabadanova, R. S., \& Polozhentseva, I. V. (2019). Practical and theoretical grounds of a student's autonomous learning activities in professional education. Amazonia Investiga, $8(20)$, 575-581.

Bundesministeriums der Justiz und für Verbraucherschutz sowie des Bundesamts für Justiz. (2007). Gesetz über befristete Arbeitsverträge in der Wissenschaft vom April 12, 2007. Available: http://www.gesetze-im-

internet.de/wisszeitvg/BJNR050610007.html 
Chairunnisa, C., \& Kosasih, A. (2019). The influence of academic culture and task commitment toward lecturers'innovativeness. The Journal of Social Sciences Research, 12(5), 1850-1854.

https://doi.org/10.32861/jssr.512.1850.1854

Deem, R. (2004). “Novyi menedzherializm” i vysshee obrazovanie: upravlenie kachestvom i produktivnostiu raboty v universitetalh Velikobritanii ["New Managerialism" and Higher Education: the management of performances and cultures in universities in the United Kingdom]. Voprosy obrazovaniia, 3, 44-56.

Dzonstoun, D. B. (2003). Sistema vysshego obrazovaniia v SSHA: struktura, rukovodstvo, finansirovanie [The USA higher education system: structure, management, funding]. University Management: Practice and Analysis, 5-6(28), 92-102.

Ergasheva, F. B. (2019). Voprosy valentnosti v sovremennom nemetskom iazyke [Questions of valence in the modern German language]. Voprosy pedagogiki, 11-2, 276-281.

Gibadulina, A. S., \& Kamneva, E. V. (2020). Materialnoe stimulirovanie prepodavatelei vuzov: zarubezhnaia praktika [Financial incentives for university teachers: foreign practice]. Economics: yesterday, today and tomorrow, 10(2A), 249-255.

Gill, R. (2009). Breaking the silence: The hidden injuries of neo-liberal academia. In: Flood, R., Gill, R. (Eds.). Secrecy and silence in the research process: Feminist reflections. London: Routledge.

Gladkikh, B. A. (2005). Sistema vysshego obrazovaniya v SSHA: osobennosti organizatsii i upravleniia [The system of higher education in the United States: features of organization and management]. Economics of education, 6, 68-89.

Glazev, S. (June 22, 2016). Glavnye otrasli-draivery novogo sprosa - zdravookhranenie, obrazovanie i nauka [The main industries that drive new demand - healthcare, education and science]. BusinessLife.today. Available: http://businesslife.today/opinions/sergej-glazev/

Goncharov, V. V., Sekerin, V. D., \& Akhyadov, E. S. - M. (2020). Digital academic entrepreneurship: new opportunities for students in the development of the information environment. Revista Inclusiones, 7(Especial), 411-421.

Government of the Russian Federation. (2008). Decree of the Government of the Russian Federation of August 5, 2008 No. 583 (as amended on January 19, 2019) "On the introduction of new pay systems for employees of federal budgetary, autonomous and state institutions and federal state bodies, as well as civilian personnel of military units, institutions and subdivisions of federal executive bodies, in which the law provides for military and service equivalent to it, the remuneration of which is carried out on the basis of the Unified tariff scale for remuneration of employees of federal state institutions" (together with the "Regulations on the Establishment of Remuneration Systems for Employees of Federal Budgetary, Autonomous and State Institutions"). Available:

http://government.ru/docs/all/64978/

Government of the Russian Federation. (2012). Order of the Government of the Russian Federation of November 26, 2012, No. 2190-r (as amended on September 14, 2015) “On approval of the Program for the gradual improvement of the remuneration system in state (municipal) institutions for 2012 - 2018 ". Sobranie Zakonodatel'stva Rossiiskoi Federatsii [SZ RF] [Collection of Legislation of the RF] 03.12.2012, No. 49, Item 6909.

Grishina, O. A., Saginova, O. V., Skorobogatykh, I. I., Zavyalova, N. B., Musatova, Zh. B., Shtykhno, D. A., \& Kovaleva, E. N. (2015). Otsenka effektivnosti prepodavatelia v sovremennom obrazovatelnom uchrezhdenii [Evaluating the effectiveness of a teacher in a modern educational institution]: monograph. Novosibirsk: TsRNS Publishing House, 114 p.

Hasselhorn, M., Baethge, M., Füssel, H. - P., Hetmeier, H. - W., Maaz, K., Rauschenbach, T., Rockmann, U., Seeber, S., Weishaupt, H., \& Andrä, W. (2014). Bildung in Deutschland. Ein indikatorengestützter bericht mit einer analyse zur bildung von menschen mit behinderung. Bielefeld: W. Bertelsmann Verlag.

Head, S. (2011). Chto ugrozhaet britanskim universitetam? [The grim threat to British universities]. Voprosy obrazovaniia, 2, 282-295.

Khudaimuratova, K. (2020). Vidy, formy obrazovaniia i trudovye otnosheniia prepodavatelei v sisteme vysshego obrazovaniia Federativnoi Respubliki Germaniia [Types, forms of education and labor relations of teachers in the higher education system of the Federal Republic of Germany]. Aktualnye nauchnye issledovaniia v sovremennom mire, 6-7(62), 149-153.

Kim, I. N., \& Lisienko, S. V. (2012). Formirovanie bazovykh sostavliaiushchikh professionalnoi kompetentnosti prepodavatelia $v$ ramkah FGOS [Formation of the basic components of a teacher's professional competence within the framework of the Federal State Educational Standard]. Higher education in Russia, 1, 16-24. 
Kleri, S. B. (2008). Zarabotnaia plata prepodavatelei vuzov SSHA v 2006-2007 uchebnom godu [Salaries of USA university professors in the 2006-2007 academic year]. Economics of education, 5, 100-103.

Kolin, K. K. (2002). Informatsionnaia globalizatsiia obshchestva i gumanitarnaia revoliutsiia. [The information globalization of society and the humanitarian revolution]. In: Egorov, V. K. (Ed.). Globalization: A synergy approach. Moscow: Russian Academy of National Economy and Public Administration under the President of the Russian Federation, pp. 323-334.

Kurbatova, M. V. (2016). Izmenenie kharaktera otnoshenii mezhdu rukovoditeliami i prepodavateliami vuzov v rezultate vnedreniia novykh instrumentov upravleniia [Changes in the nature of relations between the leaders and teachers of universities as a result of the introduction of new management instruments]. In: Theory and practice of using contractual regulation of social, labor and educational relations in institutions of higher and vocational education: Materials of the All-Russian scientific and practical conference, Ryazan, Russia, December 11-12, 2015, pp. 5-15.

Kurbatova, M. V., \& Levin, S. N. (2013). Effektivnyi kontrakt v sisteme vysshego obrazovaniya RF: teoreticheskie podkhody i osobennosti institutsional'ogo proektirovaniia [An effective contract in the higher education system of the Russian Federation: theoretical approaches and features of institutional design]. Journal of institutional studies, 5(1), 55-80.

Lazareva, G. Iu. (2020). Formirovanie i razvitie sistemy sotsialno-trudovykh otnoshenii v usloviiakh transformatsii rossiiskoi sistemy vysshego obrazovaniia na osnove balansa interesov [Formation and development of the system of social and labor relations in the context of the transformation of the Russian system of higher education based on the balance of interests]. Bulletin of the South-Russian State Technical University (Novocherkassk Polytechnic Institute). Series: Socio-Economic Sciences, 13(4), 53-61. https://doi.org/10.17213/2075-2067-2020-4-53-61

Maiburov, I. (2003). Vysshee obrazovanie v razvitykh stranakh [Higher education in developed countries]. Higher education in Russia, 2, 132-144.

Nazarova, I. B. (2014). Kontrakt universiteta s prepodavatelem: prava i obiazannosti [The contract between a university and a teacher: rights and obligations]. Educational technologies, 3, 69-77.

Orlova, N. N., \& Parshikov, N. A. (2017). Nauchno-pedagogicheskie rabotniki kak osnova effektivnosti natsionalnoi obrazovatelnoi sistemy [Scientific and pedagogical workers as the basis for the effectiveness of the national educational system]. Social-Economic Phenomena and Processes, 12(6), 235-242.

Pouyioutas, P. (2017). Key performance indicators for the teaching in Higher Education Quality Model (THEQM). In: 6th International Conference on Education and New Learning Technologies, Barcelona, Spain, July 7-9, 2014, pp. 46294640 .

President of the Russian Federation. (2012a). Decree of the President of the Russian Federation of May 7, 2012 No. 597 "On measures for the implementation of state social policy". Available: http://www.kremlin.ru/acts/bank/35261

President of the Russian Federation. (2012b). Decree of the President of the Russian Federation of May 7, 2012 No. 599 "On measures to implement state policy in the field of education and science." Available: http://www.kremlin.ru/acts/bank/35263

Rimskaia, O. N. (2006). Motivatsiia prepodavatelei vuzov v sisteme menedzhmenta kachestva obrazovaniia [Motivation of university teachers in the education quality management system]: monograph. Tomsk: Tipografiya "Grafika".

Sekerin, V. D., Gorokhova, A. E., Dudin, M. N., Danko, T. P., \& Nikolaykin, N. I. (2018). Applying interactive marketing methods to improve the quality of university educational services authors. Quality-Access to Success, 19(163), 37-42.

Sokolov, M., Guba, K., Zimenkova, T., Safonova, M., \& Chuikina, S. (2015). Kak stanoviatsia professorami: akademicheskie karery, rynki i vlast $v$ piati stranakh [How to become a professor: academic careers, markets, and power in five countries]. Moscow: Novoe literaturnoe obozrenie, $832 \mathrm{p}$.

Tambovtsev, V. L. (2006). Konechnye rezultaty otrasli obrazovaniia i problemy ikh izmereniia [Final outcomes of education and the problems of their measurement]. Voprosy obrazovaniia, 1, 5-24.

Tereshchenko, E. A., Kovalev, V. V., Trofimov, M. S., \& Zasseev, D. A. (2020). Legal consciousness as a factor promoting the achievement of educational objectives and the realization of the right to education by individuals and collectives. Revista Tempos e Espaços em Educação, 13(32), 1-21. https://doi.org/10.20952/revtee.v13i32.14690

TRUD.com. (n.d.). Salary statistics “University teacher in Russia”. Available: https://russia.trud.com/salary/692/4130.html 30406 P 
Umurakova, G. H., \& lantilina, N. T. (2018). Zarubezhnyi opyt oplaty truda v sfere obrazovaniia [Foreign experience of remuneration in the field of education]. In: Economics and Humanitarian Research: Problems, Trends, Achievements: Collection of materials of the 3rd International Scientific and Practical Conference, Novosibirsk, Russia, March 16-17, 2018, pp. 116-120.

Zhandarova, I. (November 9, 2017). MVF nazval glavnye draivery rosta ekonomiki Rossii [The IMF named the main drivers of growth in the Russian economy]. Rossiiskaia Gazeta. Available: https://rg.ru/2017/11/09/mvf-nazvalglavnye-drajvery-rosta-ekonomiki-rossii.html

Received: 13 May 2021 | Accepted: 3 August 2021 | Published: 24 August 2021

This is an Open Access article distributed under the terms of the Creative Commons Attribution License, which permits unrestricted use, distribution, and reproduction in any medium, provided the original work is properly cited. 